\title{
REPRESENTACIONES \\ POPULARES DE LA VIDA URBANA: \\ CIUDAD DE MÉXICO, 1890-1930
}

\author{
Tomás Cornejo* \\ Universidad Diego Portales, \\ Santiago de Chile
}

Ya no se puede vivir, En México y sus contornos, Pues son muchos los bochornos

Que se tienen que sufrir.

Por eso es mejor salir

Con la ollita y el metate,

La maleta y el petate,

Nuestro pedazo de fierro, Y también con nuestro perro

A echar pulgas á otra parte.

Nueva y segunda parte de los versos de echar pulgas a otra parte, sin autor, Imp. de A. Vanegas Arroyo, c. 1910.

1 siglo xix latinoamericano fue abundante en discursos
sobre la ciudad. Tuvo versiones locales de los creadores
europeos del urbanismo moderno, quienes, tal como éstos,
procuraron ejecutar más que construir razonamientos sobre Fecha de recepción: 23 de febrero de 2015

Fecha de aceptación: 27 de mayo de 2015

* Proyecto Fondecyt Posdoctorado 3130426, Conicyt, Gobierno de Chile. 
su quehacer. Tuvo también émulos de los escritores del viejo mundo que cantaron las maravillas y las miserias de las ciudades capitalistas, las cuales, a este lado del Atlántico, miraban el futuro e intentaban dejar atrás su aire colonial. Buena parte de la intelectualidad latinoamericana estuvo fascinada por la urbe moderna, entidad concreta, presta a dejarse admirar en París, e idea en desarrollo y cifra del porvenir en Nueva York.

Las transformaciones urbanas implementadas en nuestro continente, sin embargo, debieron enfrentar una serie de desafíos inéditos. Amén de la particular geografía de un territorio que se quería aún virgen en algunos países, o desierto en otros, fue el paisaje social lo más problemático. Tales desafíos tuvieron un correlato en el campo cultural, convirtiéndose en tópicos del debate público que, por medio de la prensa y la literatura, convocaron un interés general.

En el caso específico de la ciudad de México, los historiadores han tratado de acercarse a su evolución social desde la narrativa, resaltando el estudio de las décadas centrales del siglo xix hecho por Ricardo Pérez Montfort. Tal acercamiento permitiría observar dos fenómenos paralelos: lo que efectivamente sucedió en la vida urbana y los modos de representación de dicha evolución efectuados en los códigos del discurso literario. Los cambios en las costumbres, la apertura a nuevas influencias culturales, los adelantos materiales y la alteración del trazado mismo de la ciudad, hicieron retroceder la impronta colonial que subsistió hasta un par de décadas después de la independencia. Pérez Montfort detecta algunas contradicciones entre la normativa subyacente del proceso de urbanización y las prácticas festivas, en cuanto toca a los grupos populares. Éstos continuaron 
practicando sus celebraciones religiosas y profanas en lugares públicos, a contrapelo del carácter cada vez más privado y restringido (más "urbano" en el sentido de urbanidad o buenas maneras) con que las clases altas revistieron sus celebraciones. ${ }^{1}$

En una encrucijada literaria distinta, si bien muy atento al rumor de las arterias citadinas menos encumbradas, Guillermo Prieto “otorgó voz a los que no la tenían, en una sociedad donde el decoro y la elevación estaban al alcance de unos cuantos. Gracias a Prieto, la ciudad habla a través de sus usos y costumbres, de sus expresiones y mitologías". ${ }^{2} \mathrm{El}$ autor de Musa callejera supo captar en plenitud las expresiones verbales del pueblo y realizó un trabajo de transcripción del lenguaje vivo. Si buscó con ello consumar definitivamente la independencia lingüística mexicana, no debe olvidarse que en su enfrentamiento con la realidad circundante, sus dotes de observador y taxónomo minucioso lo asimilan al científico social. ${ }^{3}$

No es casualidad que una serie de registros social y culturalmente valederos que tienen a la ciudad de México decimonónica -y porfiriana en particular- por tema hayan sido elaborados por hombres como Prieto, a medio camino entre el letrado profesional y el político; ni que su formato haya sido la nota costumbrista, el relato breve o la crónica, géneros polimorfos y fronterizos entre la literatura y la prensa. ${ }^{4}$ Esta última, con todo, y a despecho de los ingentes tirajes

\footnotetext{
1 Pérez Montfort, "La fiesta y los bajos fondos", pp. 69-78.

2 Quirarte, Elogio de la calle, p. 244.

${ }^{3}$ Quirarte, Elogio de la calle, pp. 249 y 255.

${ }^{4}$ Véase Rotker, La invención de la crónica, y el trabajo clásico de Ramos, Desencuentros de la modernidad, en especial, pp. 112-142.
} 
que alcanzaría al dar vuelta 1900, amén de la segmentación de los lectores y la publicación de periódicos hecha por y para los sectores populares, continuó entregando una visión parcial sobre las transformaciones de la capital mexicana y sus habitantes. Al igual que todos los documentos utilizados para estudiar el pasado, el discurso de la prensa (y su continuación literaria) quedó impregnado por las coordenadas sociales de sus emisores, entendiendo por tales los emprendimientos editoriales y el bagaje cultural de sus autores, mismos que aspiraban a encontrar una respuesta en sus lectores implícitos. Las crónicas, canonizadas de sobra por la historiografía y consideradas una fuente documental fiable, "deberían ser escrutadas como fuentes de información no solamente sobre la ciudad real sino, también, sobre la idea que sus autores tenían de la ciudad, sobre la ciudad ideal". ${ }^{5}$

Piénsese, por ejemplo, en Ángel de Campo, cuyo reciente rescate y paralelo ingreso a la historia urbana de ciudad de México en calidad de testigo abrió un panorama antes obliterado por los historiadores sobre la cotidianeidad del espacio citadino. Su testimonio, un cuestionamiento de la visión unilateral y positivista de la modernización capitalina, fue asimismo distante de sus protagonistas más desposeídos. Carlos Illades notó, en los textos breves de De Campo, que su mirada no fue "ni positiva ni esperanzada: la pobreza se autorreproducía, y a quienes intentaban remontarla frecuentemente se les sancionaba [...], de tal manera que los afanes de progreso de las clases populares rápidamente entraban en contradicción con un orden inamovible". ${ }^{6}$

\footnotetext{
${ }^{5}$ Monnet, “¿Poesía o urbanismo?”, p. 728.

${ }^{6}$ Illades, "Pueblo y plebe”, p. 371.
} 
Contamos con un registro más próximo a estos sectores sociales y más empático con su experiencia de poblar una urbe en rápida mutación. Me refiero a la lírica popular impresa, bajo la denominación abarcadora de corrido, editada profusamente durante el último tercio del siglo XIX (aun cuando había circulado en un volumen menor desde el periodo novohispano), la cual, salvo excepciones, ${ }^{7}$ ha sido desconocida a la hora de estudiar la modernización urbana. La riqueza de esta manifestación cultural radica en su amplitud temática y su continuidad temporal. Tal como otros países del continente con versos callejeros semejantes (Brasil, Chile y Argentina), los impresos eventuales mexicanos continuaron saliendo de los talleres tipográficos cuando menos hasta finalizar la década de 1920. Ese lapso cubre el afianzamiento de la "ciudad burguesa" y permite vislumbrar el inminente desafío de la "ciudad de masas”, según caracterizó José Luis Romero el desarrollo secular del problema urbano en América Latina. ${ }^{8}$

Los corridos, largamente olvidados por los historiadores, ofrecen un sinnúmero de referencias sobre la ciudad de México. En primer término, a propósito de su remodelación física, las vicisitudes políticas de la época y el cambio general de costumbres, interpretados desde una perspectiva no oficial y en códigos propios de los márgenes del mundo letrado. En segundo lugar, informan acerca de la "vida menuda" de la ciudad en los sitios frecuentemente concurridos por las clases trabajadoras y sobre sus actividades, entre otros, Las grandes lamentaciones y triste despedida de los baratilleros al

\footnotetext{
7 Avitia, Corridos de la capital.

${ }^{8}$ Romero, Latinoamérica.
} 
pasarse para Tepito [c. 1900], Los lamentos de las tortilleras [c. 1900], Formidable inundación en la colonia Valle Gómez [1913], La carestía del comercio [c. 1910], Despedida de los carros rabones [c. 1925], Terrible explosión en la Albóndiga [1928], por recordar algunos. Lo habitual y lo extraordinario, el trabajo y la diversión, la pobreza y la esperanza de escapar de ella, afloran en textos casi siempre anónimos.

Estas composiciones dan cuenta de las dificultades enfrentadas por los sectores populares mexicanos para habitar la capital. En distintas métricas (cuartetas, contrapuntos) y con diversos tonos (jocosos, críticos, reflexivos), se dibuja un contexto donde el reordenamiento espacial fue un proceso sujeto a una disputa y renegociación continua. El interés histórico en este tipo de impresos se funda en el correlato cultural que logran aprehender, a propósito de una realidad muy concreta y acuciante para la mayoría de los nuevos urbanitas. La miríada de corridos referidos a la ciudad de México compartió una visión plebeya sobre dicho problema entre un conjunto no menor del público capitalino, vehiculando ideas y sentires al servir de guía para no iniciados en la experiencia urbana. ${ }^{9}$ De esta forma, podemos "indagar la formación de la cultura urbana y el despertar de la conciencia sobre la ciudad en una sociedad en proceso de modernización", ${ }^{10}$ comprendiendo aquélla como una entidad material concreta y localizada, pero a su vez como un conjunto de relaciones sociales continuamente resignificadas por sus habitantes. ${ }^{11}$

9 En otras latitudes, la prensa de a centavo cumplió dicha tarea. FRITZCHE, Berlín 1900, p. 34.

10 Almandoz, Entre libros, p. 211.

11 Gorelik, La grilla y el parque, pp. 16 y 19. 
En efecto, determinados rumbos cambiaron su constitución social y fueron resituados en el mapa mental de los pobladores de la agitada ciudad de los palacios cuando despuntó el siglo xx. Mientras las elites se mudaron a las nuevas colonias ubicadas al poniente, el centro aumentó su dotación demográfica debido al movimiento interno de miembros de las clases populares y a convertirse en punto de llegada de inmigrantes rurales. ${ }^{12}$ De acuerdo con estimaciones de Ariel Rodríguez Kuri, la población proveniente del campo rondó $50 \%$ para el periodo $1889-1910 .^{13}$

Inciden aquí algunos elementos culturales en el modo creado por los residentes pobres de la capital para dar sentido a su entorno. ${ }^{14}$ Por una parte, aquello identificado por Mario Barbosa como una suerte de continuidad entre la calle y la vivienda. ${ }^{15}$ Amén de la precariedad económica que impedía a algunos tener un lugar con las condiciones mínimas de higiene y comodidad, factores adicionales volvían este anhelo una cuestión más utópica. Artesanos, venteros, vendedores ambulantes y cocineras, entre otros, utilizaban un mismo espacio con dos fines aparentemente contrapuestos: productivo y habitacional. De manera complementaria, buena parte de la sociabilidad popular se desarrollaba en esos mismos ámbitos. Tanto las propias calles como las zonas liminares (zaguanes, patios, talleres, tiendas/changarros) devinieron áreas de encuentro y comunicación adecuadas para la reproducción social, y asimismo escenario de potenciales disputas. "Se quejaba un periódico días

12 Barbosa, El trabajo en las calles, p. 162.

13 Rodríguez Kuri, La experiencia olvidada, p. 87.

${ }^{14}$ De Certeau, La invención de lo cotidiano, p. 105.

15 Barbosa, El trabajo en las calles, pp. 164-169. 
pasados [noviembre de 1904] del descoco y falta de recato con que algunos vecinos de esta capital se entregan a las efusiones amorosas en plena calle y a plena luz", anotó el ya citado Ángel de Campo. ${ }^{16}$

Esta forma de habitar la urbe contrariaba la concepción moderna de ella. Atentaba, primero, contra el proyecto estético y la lógica civilizadora que autoridades y sectores dirigentes imbuían a las remodelaciones y la extensión de la superficie de la ciudad de México, por medio de la adopción de modelos europeos. ${ }^{17} \mathrm{Y}$ atentaba, además, contra el espíritu burgués que se hallaba en la base de estos últimos y de sus imitadores en el continente americano: junto con distorsionar los límites de la propiedad privada y el mercado de la vivienda, la sociabilidad popular en los mencionados espacios ponía en suspenso la frontera entre público y privado. Validada y resguardada esta última por las elites porfirianas y, con el correr de los años, por las clases medias posrevolucionarias, no fue un factor preponderante de la cotidianeidad de las familias pobres.

La visión "desde abajo" del problema quedó plasmada, verso tras verso, en las hojas volantes editadas por Antonio Vanegas Arroyo e impresores como Eduardo Guerrero, quien vivificó el rubro después de la muerte del primero. En las páginas siguientes se estudian tres ejes temáticos que iluminan la experiencia urbana popular desde las representaciones construidas por los corridos: el alza de los alquileres y el enfrentamiento con los propietarios; las reglas de

16 Campo, La Semana Alegre, p. 238.

17 Valenzuela, "Racionalidad y poder”, pp. 15-18; Aréchiga, "Lucha de clases en la ciudad". Para un punto comparativo, Outtes y Miura, "Disciplinar a la sociedad" y Pineo y BaER, "Urbanization". 
convivencia y la sociabilidad en las vecindades, y las disputas por administrar los contados recursos económicos familiares, trastocando inevitablemente las relaciones de género. Cuestión no menor la última si se recuerda que, cuando menos hasta mediados del siglo xix, la proporción de mujeres en la ciudad fue bastante mayor a la de hombres, debido a patrones inmigratorios diferenciados, por razones sobre todo económicas. ${ }^{18}$

Son éstos los temas principales, a menudo interrelacionados, los que derivan del examen de alrededor de 300 hojas volantes originales y un número menor de reproducciones facsimilares o transcripciones impresas, en un arco temporal que abarca aproximadamente de 1890 a $1930 .{ }^{19}$ Antes de su análisis, es necesario situar los materiales para validar su potencial historiográfico.

\section{UN TIPO PARTICULAR DE IMPRESO}

A lo largo de todo el siglo xix se produjo en México una cantidad admirable de hojas volantes e impresos eventuales en formatos disímiles, como folletos y cuadernillos, destinados a los sectores populares. Los más conocidos fueron confeccionados por la imprenta de Antonio Vanegas Arroyo e ilustrados por Manuel Manilla y José Guadalupe Posada. Ellos y sus colaboradores formaron una verdadera empresa

18 Arrom, Las mujeres, pp. 130-133.

19 El material más extenso corresponde a la poco explorada colección de corridos populares de la Biblioteca Daniel Cosío Villegas de El Colegio de México, compuesta por 277 hojas en muy buen estado de conservación. A ello se suma una veintena de ejemplares originales de la Colección Andrés Blaisten, todos editados en la ciudad de México. 
comercial, abocada a diversas modalidades literarias de incipiente consumo masivo. ${ }^{20}$ Sus publicaciones, creadas por escritores y grabadores con algún grado de instrucción, amalgamaron temas tradicionales y novedosos, utilizando expresiones de honda raigambre entre las clases trabajadoras, donde radicó su efectividad para multiplicar las ventas y empatizar con su audiencia.

Antonio Vanegas Arroyo, el prolífico editor, falleció en 1917, apenas cuatro años después que Posada. Los herederos de aquél continuaron reimprimiendo las hojas más demandadas por varios años, a las cuales añadieron títulos inéditos, reutilizando las imágenes creadas por el célebre grabador. En la década siguiente nuevos talleres tipográficos ingresaron al ruedo. Entre ellos destaca uno muy feraz -si bien menos calificado-, la Imprenta de Eduardo Guerrero. Ubicada, tal como la casa Vanegas, en pleno centro de la ciudad de México, el formato de sus hojas volantes retrucó el de aquella, de probado éxito: papel de color, de mala calidad y precio de venta bajísimo, aunque, a diferencia de los instauradores del modelo original, incorporaron material gráfico de menor categoría (fotografías y caricaturas tomadas de otros impresos, mayoritariamente, carentes de relación directa con el texto).

Sobre las condiciones de circulación y recepción de los corridos, ${ }^{21}$ Rubén M. Campos, contemporáneo de los cultores de las primeras décadas del siglo xx, atestiguó cómo las

20 Speckman, “Cuadernillos”; Bonilla, “Imágenes”; López Casillas, Manilla.

21 Los debates sobre el origen y la filiación de esta práctica cultural sobrepasan con mucho el interés de este artículo. Para ello, véase Mendoza, El romance y, más recientemente, GonzÁLEZ, “El corrido”. Para anteceden- 
audiencias plebeyas se reunían en torno a los cantores, además de la implementación, por parte de ellos, de la versión impresa de su oficio vendida a un precio ínfimo, convirtiéndose en "propagadores del arte popular". ${ }^{22}$ Otro tanto apuntó Celestino Herrera, certificando que los impresos se distribuían en mercados y tianguis de prácticamente todo el país todavía a principios de la década de 1930. El público comprador de las hojas "en papel en chillantes colores y con truculentas ilustraciones" se componía con frecuencia de "las 'gatas' [sic] sentimentales que aprenden esos cantos llenos de la dulzura del pueblo, mientras piensan risueñamente en el gendarme o en el 'chafirete' que se les ha metido muy adentro del corazón". ${ }^{23}$

Vanegas, en tanto, desde 1880 contó con una imprenta propia en la ciudad de México, luego de haberse independizado de la paterna. ${ }^{24}$ Es decir, ya conocía de sobra el negocio, permitiéndole esto explotarlo durante las dos décadas en que colaboró con Posada. Cuadernillos y hojas volantes editados por Vanegas se podían comprar en su propia imprenta, ubicada en la calle de Santa Teresa, mientras que su contenido era amplificado por "los papeleros de encrucijada [que] declamaban a gritos ante el corro de pelados, y que aparecían depositados en las mesitas de pino que decoraban la entrada de las iglesias". ${ }^{25}$ Se estima que sus tirajes

tes de su elaboración ibérica, tanto oral como impresa, Marco, Literatura popular y BOTREL, Libros.

22 Campos, El folklore literario, p. 233.

${ }^{23}$ Herrera, Corridos de la revolución, p. 4.

${ }^{24}$ Speckman, "Cuadernillos", p. 391.

25 Campos, El folklore literario, p. 373. La contigüidad entre impresos baratos de distinto formato y el comercio ambulante de mercaderías 
podían variar entre 500 y 2000 ejemplares, y llegar a 6000 en casos excepcionales (como fue la entrada de Zapata en la capital), a la par que cada año, la imprenta enviaba a provincia unos 250000 impresos. ${ }^{26}$

En la labor de edición de los textos el impresor trabajaba asistido por algunos obreros, en tanto su creación fue encomendada a un grupo de escritores profesionales sin mayor fama ni pretensión literaria alguna, a menudo supervisado y apoyado por el propio Vanegas. ${ }^{27}$ Esto era sólo una parte de la actividad productiva. Las infaltables imágenes incorporadas dependiendo del tipo de publicación, se realizaban no sólo por otras manos, sino en otro lugar. Durante sus primeros años de actividad, Vanegas encargó las ilustraciones a Manuel Manilla. Éste era un grabador bastante conocido y versátil en el medio tipográfico, quien tampoco trabajaba solo, sino secundado por alguno de sus hijos y otros operarios. En su caso se trataba de un verdadero taller profesional de grabado, donde se realizaban trabajos comerciales de diverso tipo y no exclusivamente para la casa Vanegas Arroyo. ${ }^{28}$

Con José Guadalupe Posada la relación se estableció en términos semejantes. El impresor solicitaba las imágenes, según las necesidades de tema y de formato que se le presentaban, ya para la tapa de uno de sus cuadernillos, una de sus series más o menos regulares con personajes como

variadas era habitual durante la segunda mitad del siglo XIX. GARCía Cubas, El libro de mis recuerdos, p. 219.

26 Giménez, Así cantaban la revolución, p. 52 y Speckman, "Cuadernillos”, p. 395.

27 López Casillas, José Guadalupe Posada, pp. 21-22.

${ }^{28}$ López Casillas, Manilla. 
don Chepito Mariguano, las periódicas calaveras, o las más ocasionales hojas sueltas o volantes. Posada, quien también dio muestras infinitas de versatilidad y pericia en el manejo de los recursos gráficos, tenía a su vez un taller propio. Tal mecánica de trabajo, añadida a una labor tan prolífica como la llevada a cabo por el grabador, induce a situar el suyo como un arte de la fugacidad y lo irrepetible. Sin embargo, Posada creó con el correr de los años un repertorio gráfico más o menos estable. Ciertas temáticas de estos soportes pasajeros se repitieron insistentemente durante las décadas de 1890 a 1910, creando incluso "tipos" a la mano para ser estampados cuando se necesitara. ${ }^{29}$ Con imágenes, o bien con textos escritos en prosa o verso, los impresos eventuales del México de entre siglos crearon un elenco reconocible de representaciones sociales que, independientemente de su actualización concreta en uno u otro momento, entregaban una lectura cultural del entorno.

Este particular formato impreso permite acercarse a los intereses de las clases populares de la ciudad de México, sin considerarlas ahistóricamente manifestaciones de una identidad inmutable. Dejando para otra oportunidad el análisis del contenido iconográfico, nos abocaremos aquí a los textos. El discurso poético de los corridos, si bien no es un conjunto articulado o emanado de una figura autoral, refiere al entorno extra textual, describe con voces ingeniosas el tráfago callejero, la ocupación espacial, las miserias y también las alegrías de la convivencia urbana. Además de ser descriptivas, las composiciones son críticas, al expresar públicamente un juicio sobre las situaciones expuestas y sus protagonistas.

${ }^{29}$ Freeman, “The making”; Gretton, "De cómo fueron hechos”. 
Ahí radica su riqueza como registro histórico para adentrarse en la visión popular sobre la transformación de la ciudad. De la mano con la modernización material, refieren la constitución social del paisaje citadino, construyendo con su peculiar lenguaje un conjunto de representaciones sobre los habitantes de toda condición.

¿Qué tan “popular” fue esta modalidad impresa? ¿Cuánto hubo en ella de negocio, cuánto de impostación de una voz plebeya emanada desde otro nicho social? Difícil es responder eso a ciencia cierta. Si lo es para la cultura de masas actual y sus derivaciones electrónicas recientes, tanto más para una formación pretérita como la que interesa escudriñar. En el interior de la República, los cantores trashumantes que creaban o transmitían los corridos eran considerados "hombres de mundo", muy viajados y experimentados, quienes traían el relato de "sucesos y acontecimientos salientes que constit[uían] una novedad para esas regiones apartadas en donde la prensa [era] un lujo". ${ }^{30}$ En la ciudad, en cambio, donde el contacto (no digamos necesariamente la lectura cabal) con los impresos era habitual, la situación fue diferente. Ello no impidió que las hojas sueltas mantuvieran una amplia circulación en paralelo al aumento de los periódicos "de a centavo", hecho indicativo de su buena acogida entre el público urbano. ${ }^{31}$

El punto es complejo. Por una parte, según un conocedor avezado, Rubén M. Campos,

\footnotetext{
${ }^{30}$ Mendoza, El romance español, pp. 144-145.

${ }^{31}$ Campos, El folklore literario, p. 371. Sobre el campo periodístico, CasTILLO, "El surgimiento".
} 
[...] las hojas impresas son documentos por los que se sabe el verdadero sentir de la opinión popular representada por el coplero de antaño. Así pasaron muchos años, sin que la opinión popular, la de la plebe, no la opinión del clisé periodístico, que se refiere a la opinión personal de los editorialistas de un diario, tuviera otro desahogo que el panfleto cáustico anónimo, que impreso era de un positivo influjo en el alma de la plebe. ${ }^{32}$

Por otra, según fue avanzando el siglo xx -y volvieron a delinearse los rasgos de lo nacional y lo popular después de la revolución-, "con frecuencia considerable, poetas que no son del pueblo, particularmente propagandistas, han tratado de escribir canciones imitando el estilo popular con la intención de que sus composiciones encontraran buena acogida entre la gente común e influenciaran su modo de pensar". ${ }^{33}$

Dadas sus características de producción, cabría situar los corridos mexicanos impresos en pliegos u hojas volantes como una "fórmula editorial", en el entendido de que sus textos amalgamaban varias posiciones enunciativas y recursos lingüísticos, y de que sus productores no necesariamente compartían con el público al cual se dirigían unas mismas coordenadas socioculturales. ${ }^{34}$ Esto no quiere decir que nos enfrentemos a un material falaz, a una falsificación ideológica de los sectores populares, precaución necesaria y tenida en cuenta por la historia cultural desde hace bastantes años. ${ }^{35}$

32 Campos, El folklore literario, p. 371.

${ }^{33}$ Simmons, The Mexican Corrido, p. xi. Cursivas en el original.

34 Chartier, "Lecturas populares", pp. 170-178. Para el Brasil contemporáneo véase ABreu, Histórias, p. 25.

35 Joyce, Visions, pp. 230-255; Elkins, “The Voice”; Chartier, "Lecturas populares" y los alcances de este autor, Carlo Ginzburg y Peter Burke a los trabajos pioneros de Bollème, La Bibliothèque Bleue. 
Atiéndase, sin ir más lejos, al aspecto lingüístico. Los impresos eventuales en cuestión constituyen un reservorio de expresiones antiguas (incluyendo tópicos y fórmulas narrativas ibéricas transmitidas oralmente) y un muestrario de términos nuevos. Ellos mismos atestiguan la capacidad de los sectores populares para adaptarse a unas circunstancias y a un espacio nuevos. En opinión de Rubén M. Campos, aquí podemos encontrar las expresiones diarias de la vida popular, que "invadió las ciudades y las aulas": "La manera de hablar de la urbe no fue a la gleba, sino que la expresión de la gleba vino a la urbe, y como evidentemente los doctos no iban a hablar un lenguaje para ellos primitivo y grosero, la nueva habla halló excelente propagación en el pueblo de las ciudades que no concurre a las aulas". ${ }^{36}$ Ello explica que los corridos se alejen en forma y fondo de los registros oficiales y sus formas literarias, aun cuando tengan puntos de encuentro constante.

Esto habla de la relación con la vigencia de la cultura impresa y el tamaño del mercado editorial mexicano, su diversificación y complejidad, que para la segunda mitad del siglo XIX eran altas, pese a no contar con grandes tasas de alfabetización. ${ }^{37}$ Y se aplica, sobre todo, a la producción de Vanegas y Posada, que parece haber alcanzado réditos por medio de un sistema casi industrial para editar impresos efímeros. Tal logro tuvo emuladores en las décadas de 1910 y 1920 en la propia ciudad de México, el principal de los cuales fue Eduardo Guerrero, cuya imprenta estaba en la calle del Correo Mayor, menos afortunados al parecer

\footnotetext{
36 Campos, El folklore literario, p. 375.

37 Girón, "La folletería”.
} 
y también menos ilustrados en cuanto a bagaje letrado y recursos plásticos. Una cantidad importante de sus corridos refiere asimismo cómo fue aventurarse en una ciudad cada vez más agitada.

ALQUILERES POR LO ALTO Y PROPIETARIOS POR LO BAJO

El problema de la vivienda, crónico hoy en la capital mexicana y en las grandes urbes de América Latina, tuvo especial relevancia durante el porfiriato. Si bien la ciudad de México no contaba con la gran concentración poblacional que adquirió décadas después, sí experimentó un aumento constante. Se abrieron nuevas colonias destinadas sobre todo a sectores medios y altos (con urbanización deficitaria en muchos casos y pretensiones de diferenciación social en otros), mientras que las clases trabajadoras encontraron refugio en algunos rumbos céntricos y en colonias recientemente levantadas hacia el oriente. ${ }^{38}$

Ángel de Campo, observador siempre agudo de su entorno, afirmó en 1902 que dos terceras partes del ingreso de las familias más modestas se destinaban a solventar su habitación. Los propietarios pedían "por un alquiler precios exorbitantes, imponen condiciones sangrientas, arman con facultades vejatorias a sus cobradores y porteros; se niegan a emprender composturas, violan solemnes contratos y empujan a sus inquilinos a la vida nómada". ${ }^{39}$ Para los últimos, el alquiler se tornó una de sus preocupaciones más acuciantes y alcanzó, durante estos años, un sentido vinculado

38 Aréchiga, "Lucha de clases en la ciudad", p. 26.

${ }^{39}$ Campo, La Semana Alegre, p. 178. 
con la experiencia de residir -o intentar hacerlo- en la gran ciudad. ${ }^{40}$ Esto quedó estampado en los corridos con distintos matices y de forma reiterada.

"¡Ay, amigos, qué arranquera!/ Ya no hay para los frijoles,/ Menos para la casera”, ${ }^{41}$ exclamó uno de aquellos, en tanto otro recordaba que los días de pago eran una calamidad cotidiana: "Cada mes se llega un día/ En que se cumple la renta,/ El ombligo se me avienta/ Y me da hasta alferecía,/ Y mi esposa del alma mía/ Dice: de hambre yo me muero". ${ }^{42}$ Tal como en este caso, la principal razón esgrimida para sentir el alquiler como una penuria era la precariedad económica. Las hojas volantes repiten esta idea, señalando: "Los sastres quieren dinero/ En la tienda; en el mercado/Y eso es lo que menos hay...// Plata quiere el zapatero;/ Ya el casero está enojado/ Y todos cobran... jcaray!”. ${ }^{43}$ Para justificarse, se invocaba la empatía con los receptores de los versos: "Figúrate, lector mío,/ Que tengo tres chamaquitos,/ Tres cuñadas y mujer.../ Del pesar yo desvarío,/ Pues están los pobrecitos/ Hace ocho días sin comer.../ ¡Cómo me puede alcanzar/ Lo que gano en mi trabajo,/ Que son cuatro reales diarios,/ Si todo tan caro está!". ${ }^{4}$

\footnotetext{
${ }^{40}$ Rodríguez Kuri, La experiencia olvidada, p. 88.

${ }^{41}$ Sin autor, La Arranquera, Testamentaría de A. Vanegas Arroyo, sin fecha. BDCV, Corridos Populares, 139.

${ }^{42}$ Sin autor, ¡Ah, qué chula eres, Pachita!, Imp. de Antonio Vanegas Arroyo, sin fecha. BDCV, Corridos Populares, 181.

${ }^{43}$ Sin autor, La pobreza reinante, Imp. de Antonio Vanegas Arroyo, 1912. BDCV, Corridos Populares, 193. Una idea similar en Sin autor, Señora, su conejito ya no le gusta el zacate, Imp. de Antonio Vanegas Arroyo, 1903. BDCV, Corridos Populares, 216.

${ }^{44}$ Sin autor, La pobreza reinante, Imp. de Antonio Vanegas Arroyo, 1912. BDCV, Corridos Populares, 193.
} 
La situación desmedrada de las clases trabajadoras, aunada a la crisis económica de principios de siglo y la inestabilidad producida por la revolución, podía convertir a la gran ciudad en un lugar inhóspito para los recién llegados. Las dificultades para conseguir vivienda tenían asimismo un lado burocrático, el cual enfrentaba a los aspirantes con un verdadero meandro de procedimientos. Según unos versos de la Imprenta Guerrero, si "quieres alquilar un cuarto/ que te gane cuatro pesos,/ tienes que hacer un contrato/ por diez años cuando menos", requiriéndose más que una serie de competencias letradas, puesto que se debía "gastar diez pesos en timbres,/ dar un año adelantado/ y que firme algún banquero/ contrato certificado". ${ }^{45}$

Esta hoja resulta particularmente sugestiva de la mirada plebeya hacia el problema de la vivienda. Fue editada hacia fines de la década de 1910 o inicios de la siguiente y compendia varios niveles discursivos sobre el tema. El texto parte haciendo un llamado de oposición contra los propietarios: "Laurito, hay $[s i c]$ viene el casero,/Laurito, no pagues renta,/ Laurito, dale tres palos/ Si el recibo te presenta", con un alegato muy atendible, ya que "no es justo que por vivir/ En pieza estrecha, arruinada,/ Te cobren de renta al mes/á centavo la pulgada". Se pinta, en consecuencia, un panorama muy sombrío y asoma una visión clasista del asunto. El autor anónimo pronostica que "si las cosas siguen peor/ que como se están poniendo/y sigue el rico ordenando/ y el buen pobre obedeciendo.// Nos van a cobrar el aire,/ nos van a alquilar el Sol,/ nos van a vender la noche/ y hasta la

${ }^{45}$ Sin autor, Mañanitas de Laurito, Imprenta Guerrero, sin fecha. BDCV, Corridos Populares, 132. 
lluvia, señor". ${ }^{46}$ Todo lo anterior desemboca en situaciones que llaman a acciones directas: "Ya estoy harto de caseros,/ cuando llega el día primero/ quisiera ser dinamita/ y hacer explosión con ellos". ${ }^{47}$ Los versos no pueden dejar de vaticinar: "algún día seremos ricos/ y los ricos serán pobres, / y entonces es lo bonito, ¡Pónganse changos, señores!// Nos van a pagar con rédito/ todas las que nos han hecho". ${ }^{48}$

Sin embargo, esta consigna revolucionaria es alcanzada, cuarteta tras cuarteta, echando mano de una tradición cultural muy antigua, la sátira. ${ }^{49}$ Para graficar el rencor de los pobres urbanos contra los caseros, los versos degradan simbólicamente a estos últimos. El lenguaje satírico escogido es incontrarrestable, en la medida en que recurre al humor escatológico. El narrador relata que su casero "un día me fue a cobrar/ al estar en el común,/ al presentarme el recibo/ oyó que le dije ipum!...//Y el propietario asustado/ fue y trajo una escolta luego/ diciendo que le hice fuego/ por la renta haber cobrado". Las excusas dadas ante la policía no fueron suficientes y "me llevaron al Juzgado/ mayor de lo criminal/ por haberle disparado/ al casero hijo de un tal". Enfrentado al rigor de las formas jurídicas, el protagonista es capaz de acabar con todo decoro en aras de alcanzar la verdad. La escena habla por sí misma:

\footnotetext{
${ }_{46}$ Sin autor, Mañanitas de Laurito, Imprenta Guerrero, sin fecha. BDCV, Corridos Populares, 132.

47 Sin autor, Mañanitas de Laurito, Imprenta Guerrero, sin fecha. BDCV, Corridos Populares, 132.

48 Sin autor, Mañanitas de Laurito, Imprenta Guerrero, sin fecha. BDCV, Corridos Populares, 132.

49 Véase el estudio clásico de Bajtin, La cultura popular.
} 


\author{
Entrégueme la pistola, \\ me decía el Juez apurado, \\ -Es de igual marca la suya: \\ véngase p'al excusado. \\ Me acompañó de buen modo; \\ los calzones me tumbé \\ y empezando, puja y puja \\ otra descarga logré. \\ Esos son tiros de salva, \\ me dijo el Juez convencido; \\ más por falta de respeto \\ usted queda detenido. ${ }^{50}$
}

La denuncia, devenida risotada, es tanto o más efectiva en transmitir su mensaje, teniendo una convocatoria potencialmente mayor, tal vez, que uno elaborado en tono polemista y de confrontación. Porque junto con el triunfo moral del protagonista de la hoja, identificado con las vicisitudes de los inquilinos de vecindades y otras formas de habitación popular, se pone en evidencia las exacciones del mercado inmobiliario. Los propietarios contaban con el resguardo de la fuerza pública y del aparato judicial, es decir, una institucionalidad al efecto para sancionar un modo inicuo de proveer una necesidad tan básica.

En este corrido dos estrategias simbólicas parecen aunar fuerzas para enfrentar un enemigo más poderoso en su propio terreno, la visión clasista y el humor que desacraliza. El escenario citadino fue el adecuado para que las clases populares mexicanas crearan un nuevo capítulo de una lucha

50 Sin autor, Mañanitas de Laurito, Imprenta Guerrero, sin fecha. BDCV, Corridos Populares, 132. 
cultural con innumerables episodios. Interesante es constatar cómo, en los años inmediatos a la revolución, se expresa una actitud de franco desdén hacia el orden social. Como bien notara Rubén M. Campos, "la ironía y el descreimiento son los dos pedales del orquestrión de la plebe, presto a inflar sus fuelles a cualquier viento revolucionario". ${ }^{51} \mathrm{En}$ efecto, el ataque contra los ricos se funda, en este caso, en una burla hacia todo el aparato ideológico que sostiene su supremacía, incluyendo las leyes y sus ejecutores, además de su más vil encarnación en la ciudad, la vivienda como estratagema para un lucro descarado. La propiedad privada y el mercado inmobiliario, piedra angular de la modernización urbana -a imagen del modelo parisino de Haussmann- y enaltecido por los “privilegiados de la fortuna”, eran ponderados con ojos muy distintos por los desposeídos.

\section{VECINDADES ADENTRO Y AFUERA}

Similar intención satírica desplegaron otros corridos para dar cuenta de las noches y los días dentro de las vecindades. Corresponde, en este caso, a una sátira burlona, en búsqueda de la sonrisa cómplice, por medio del bosquejo de tipos sociales y la crítica de costumbres, algunas de las cuales podían ser muy novedosas o estar en plena adaptación al espacio de dimensiones reducidas enfrentado por las clases trabajadoras de la capital desde las últimas dos décadas del siglo xix.

“¡Miguel, no diviertas a la vecindad!”, advirtieron unos versos publicados en 1912, "Pobre de tu vieja, Miguel;/

${ }^{51}$ Campos, El folklore literario, p. 106. 
¿qué culpa tiene de ser tan fea?/ No creas que nadie la vea,/ ¡Miguel, no diviertas a la vecindad!” ${ }^{22}$ Cuatro años después, otra hoja suelta describió en tono socarrón las características más notables de los habitantes de una vivienda colectiva: "Enfrente del número ocho/Viven unas catrincitas/ Que trabajan el bizcocho/ Pa llenarse las pancitas", mientras que "Junto al cinco hay una gata/ Que las porta de caderas,/ Pero que la muy ingrata/ Se pone las sudaderas". ${ }^{53}$

Los textos en cuestión trazan, con léxico y gracia particulares, descripciones acertadas de los múltiples microcosmos sociales dentro de los recintos habitados por las clases trabajadoras. Se comprueba que en las vecindades había una interacción social muy alta, poniendo en obligado contacto a sus residentes, algunos de los cuales podían tener estatus diferentes a otros inquilinos y rehuir por tanto la comunicación. Del conjunto de representaciones sobre la cotidianeidad de los pobres urbanos, se colige que la convivencia era una instancia sujeta a negociaciones constantes y donde la evaluación de los demás respecto a costumbres e imperativos tradicionales podía tensionarse con aquellos adquiridos en el escenario citadino. Mientras que la crítica moral fue asimismo el cometido de ciertas hojas volantes, en otras se establecieron valoraciones claras sobre algunas figuras vueltas prototípicas de la sociabilidad popular del periodo. Si los propietarios de las vecindades eran el enemigo declarado, sus emisarios femeninos, las caseras o porteras,

52 Sin autor, El pagaré o sea la mujer chismosa de la vecindad, Imp. de Antonio Vanegas Arroyo, 1912. BDCV, Corridos Populares, 154.

${ }^{53}$ Sin autor, El nuevo corrido, vida y muerte de la cucaracha [Testamentaría de A. Vanegas Arroyo], 1916. BDCV, Corridos Populares, 232. 
ocuparon también un sitio destacado en el imaginario de la época. ${ }^{54}$

Dicha situación fue un tópico de la poesía popular impresa. En un corrido se narra cómo la casera, después de abrir a las seis de la mañana el zaguán, "gruñendo y regañando,/ Así acaba su limpieza,/ Y a cobrar con los recibos/ A los vecinos empieza// -Buenos días, doña Teresa,/ Dice en el cuarto primero,/ Aquí les traigo el recibo/ Porque ahora viene el casero", y la interpelada, irónica: "-Pues ahora no hay dinero/ Responde en cólera llena/ La vecina, que en palacio/ No me han dado la quincena", y al punto espeta "Ya se puede usted largar/ De mi casa, vieja tuerta,/ Ni un pie vuelva usted a parar/ En el umbral de mi puerta". ${ }^{55}$

Otra hoja volante relata un episodio imaginario, aunque bastante plausible de haberse verificado, entre la casera de una vecindad y sus moradoras. La encargada de la vivienda de alquiler parte quejándose: "Ah, qué viejas tan catrinas/ Tengo en esta vecindad,/ Retobadas y bufonas/ Que es una barbaridad.// No respetan mi mandao, / Me tratan hay como quiera $[s i c]$, / Como si fuera su igual,/ No ven que soy la casera". ${ }^{56}$ La forma escogida por la protagonista para intentar marcar las barreras sociales que, a su juicio, han quedado en suspenso, se verifica mediante la observación y

${ }^{54}$ Alcanzó el rango de tipo social urbano en Los mexicanos pintados por sí mismos, ya en la década de 1850. Su persistencia llevó a que en 1879 comenzara a publicarse en la ciudad de México el semanario satírico ilustrado La Casera, el cual en la década de 1890 volvería a editar Manuel Manilla. Véase López Casillas, Manilla, pp. 182-183.

${ }_{55}$ Un pleito de vecindad como es la pura verdad, reproducido en López Casillas, Manilla, p. 119.

${ }^{56}$ Sin autor, La casera disputona, Imprenta Guerrero, sin fecha. BDCV, Corridos Populares, 39. 
el comentario. Ocupa una posición estratégica en la arquitectura del inmueble, habilitándola para reprochar moralmente a sus residentes, en particular las femeninas: "Esa del número uno/ Ah cómo le gusta el trago,/ También le gustan los hombres,/ Porque es del ganado bravo.// La seca que habita el dos/ Nunca tira la basura,/Y su ético muchacho/ En donde quiera se surra [sic]". ${ }^{57}$

En el mismo tono la casera repasa a siete inquilinas, pero su malestar se acrecienta cuando recuerda que ninguna ha cumplido con sus pagos. Aquello la vuelve una defensora fiel de la propiedad y enemiga de los moradores del inmueble: "Voy a avisarle al señor,/ Nomás que haga la limpieza,/ Que han de vivir de gorra/ Se les puso en la cabeza.// Qué gente tan descarada/ También tan sinvergüenzonas,/ Seguro la vecindad/ La hicieron las palomas" ${ }^{58}$ El episodio concluye mal para el personaje aludido, ya que, cansada de sus habladurías, "una vecina/ Salió y le tumbó los dientes", sumándose otras habitantes del lugar en un castigo ejemplar para aquella. Este resarcimiento simbólico contra un personaje común en el paisaje social de ciudad de México ${ }^{59}$ arroja nuevas luces contrastado con otras latitudes.

En el París decimonónico, las representaciones literarias y visuales situaron a las porteras como una intromisión de los

${ }^{57}$ Sin autor, La casera disputona, Imprenta Guerrero, sin fecha. BDCV, Corridos Populares, 39.

${ }^{58}$ Sin autor, La casera disputona, Imprenta Guerrero, sin fecha. BDCV, Corridos Populares, 39.

${ }^{59}$ La casera también podía ser aludida como "portera" y tener eventualmente un desempeño positivo, actuando de mediadora en una disputa doméstica. Sin autor, Reciente pleito de casados, que si no riñen están enojados, Imp. de Antonio Vanegas Arroyo, sin fecha. BDCV, Corridos Populares, 160. 
cuerpos plebeyos en el espacio habitacional de la burguesía. Fue un tipo urbano moderno para un tipo de vivienda igualmente moderno, funcionalmente bello según los cánones del urbanismo que diera un nuevo aspecto a la ciudad luz. ${ }^{60} \mathrm{En}$ México, por el contrario, de preferencia no se levantaron nuevas edificaciones para lucrar con la renta de la propiedad inmueble en los barrios centrales. Éstos aumentaron en densidad habitacional, pero mayoritariamente debido al acondicionamiento y la subdivisión de propiedades antiguas. ${ }^{61}$ Sus moradores ostentaban rasgos peculiares, considerando su extracción social y cultural, ya que las vecindades fueron ocupadas sobre todo por hombres y mujeres de las clases trabajadoras. La casera del corrido citado, en consecuencia, cumple una función mediadora hacia abajo en la escala social, velando por los intereses del propietario y remarcando los diferentes estatus de ella misma, su mandante, y los ocupantes del edificio.

Un aspecto complementario a considerar es que la casera funja, en este universo literario, como mentís a las pretensiones de modernidad e imitación metropolitana. Tales pretensiones formaron parte de un entramado cultural mayor, con sus propios textos, producidos por y para un circuito letrado más bien restringido, fascinado con las promesas de las grandes urbes y presto a creer que la ciudad de los palacios se encarrilaba por la misma vía. ${ }^{62}$ En cambio, en los impresos eventuales analizados, caseras y porteras corporeizan la trastienda de ese constructo halagüeño, encargándose

${ }^{60}$ Marcus, Apartment Stories, pp. 42-50.

${ }^{61}$ Barbosa, El trabajo en las calles, p. 162; Valenzuela, "Racionalidad y poder", p. 13.

${ }^{62}$ Quirarte, Elogio de la calle. 
del aseo, la vigilancia y la cobranza, es decir, permitiendo circular al capital y que la renta del suelo adquiera vigencia como mercado legítimo, elementos primordiales en la modernización urbana decimonónica, ${ }^{63}$ pero posibilitando a su vez a los capitalistas ausentarse del momento ominoso del cobro y la presión derivada del mismo.

Es llamativo también, desde la mirada popular, el tipo de control social ensayado por la casera. Su celo tiene obviamente un interés económico, aunque es además una vigilancia moral y moralizante, bastante cercana a los mecanismos de reproducción social de las comunidades rurales y de la sociedad tradicional latinoamericana. Las herramientas para implementarlo son, como resulta lógico, la mirada y la palabra, respecto de las cuales la casera es secundada por los inquilinos. Esos códigos culturales compartidos giran en torno a un tema de infinitas gradaciones, el estatus, construido a base de evaluaciones constantes de los demás y la presentación pública de los individuos. Tanto en la poesía popular impresa como en innumerables expresiones culturales de la época, "igualados" e "igualadas" son objeto de crítica y obligan a los interlocutores a una dinámica de reposicionamiento continuo en la escala social. Y ésta pareciera ser, en los albores del siglo xx, una donde la opinión pública comunitaria, forjada en patios, escaleras y lugares de encuentro en las vecindades, tenía mucho que decir.

De la misma forma, el actuar de la casera y los espacios fronterizos en los cuales se mueve cuestionan un factor importantísimo del modelo civilizatorio occidental decimonónico, "el deseo burgués de la separación entre lo público

${ }^{63}$ Harvey, París, pp. 161-180. 
y lo privado, la aspiración de la privacidad como triunfo de la intimidad, de la individuación, de la elevación social y del ingreso a la modernidad". ${ }^{64}$ La precariedad material de las habitaciones en las vecindades y sus estrechas dimensiones contribuían en buena medida a ello, viéndose reforzado por unas pautas de convivencia más próximas a la apertura que a la interposición de barreras físicas infranqueables.

Lo anterior puede comprobarse en aquellas hojas volantes que recrean un clima de camaradería ameno muy propio de los rumbos populares. En plena década de 1920, dos comadres hilvanan los comentarios de la actualidad política y la economía al son de un lubricante social, ya desde el saludo: "Muy buenos días, Comadrita,/ ¿cómo está la vida mía?/ Tómese usté una copita/ Para no sentir el día.// Siéntese usté un momento,/ hada de mi corazón,/ platíqueme algo del tiempo/y de la actual situación”. ${ }^{65}$

Los efectos de la revolución constituyen la parte medular del diálogo, demostrando haber significado una serie de experiencias nuevas para la población de la ciudad de México. ${ }^{66}$ Entre ellas, claro está, un aprendizaje político, aunque con modulaciones particulares entre los sectores populares, por haberse visto alterada la economía doméstica en igual magnitud que la propia constitución familiar. En la visión de estas "comadritas", "yo no siento ni hago caso,/ pero tampoco me dejo/ por causa del ramalazo,/ se llevaron a mi viejo.// Ay! comadrita de mi alma!/ es grande pena y dolor,/

${ }^{64}$ Viveros, "De puertas adentro", p. 124.

${ }^{65}$ Chávez, Guadalupe, Plática de dos comadres, sin imprenta, sin fecha. BDCV, Corridos Populares, 124.

${ }^{66}$ Véase Rodríguez Kuri, Historia del desasosiego. Sobre la épica popular, Herrera, Corridos. 
hay que sufrir con la calma/ pues el mío era cargador”. Un lenitivo muy moderno era el acompañante perfecto: "Hay que olvidar las tristezas/ al fin ya nos tocaría,/ vamos a tomar cerveza,/ sólo así me olvidaría". ${ }^{67}$ La respuesta de la imaginaria comadre corrobora lo dicho y agrega una faceta sobre la manera creativa en que se adaptaron durante esos difíciles años las mujeres de los grupos subalternos:
Desde la muerte de Villa
Comadre, es un padecer, todo a causa de la Silla que todos quieren poseer. Pues á mí nunca me falta Trabajar de tortillera, Es la fábrica más fácil Que tenemos en la tierra. Adónde está el paradero de tantos levantamientos desde don Pancho Madero son grandes los sufrimientos. ${ }^{68}$

Las instancias de sociabilidad informal funcionaban con más de un cometido. Aparte del eventual control antes mencionado, el patio o el zaguán de las vecindades, las entradas de las viviendas en algunas calles y puntos similares de encuentro casual se volvieron habituales en la cartografía popular. Al intercambio verbal mal intencionado se sumaba

${ }^{67}$ Chávez, Guadalupe, Plática de dos comadres, sin imprenta, sin fecha. BDCV, Corridos Populares, 124.

${ }^{68}$ Chávez, Guadalupe, Plática de dos comadres, sin imprenta, sin fecha. BDCV, Corridos Populares, 124. 
el amistoso y aun aquel que cimentaba redes de intercambio y solidaridad, tanto más necesarias en un escenario alejado de las comunidades de origen de muchos nuevos capitalinos. Esos lugares de reunión e interacción social de los rumbos populares eran, asimismo, escenario de actividades productivas y económicas. ${ }^{69}$

Si algo de esto asoma en el diálogo recién citado, otro tanto reluce en un corrido previo a 1900. En él se informa cómo un barillero podía redimir una jornada de malas ventas en los aledaños de la ciudad de México: "Dejémonos de desatinos/Vámonos por la ciudad/ Que las gentes por aquí/ Nunca tienen caridad". Dicho aspecto contrastaba con la sociabilidad abierta de un barrio populoso dentro del radio urbano: "en esta vecindad/ Veo la gente alborota,/ Miro muchos farolitos/Y también veo la enramada". ${ }^{70}$ Unas pautas de comportamiento que recreaban en suelo urbano las prácticas pueblerinas, así como el uso intensivo de los espacios semiabiertos, ni del todo públicos ni del todo privados, dieron en configurar una cultura particularmente vivaz en las colonias pobres. Fue éste un proceso de adaptación recreado en las hojas volantes dirigidas al público menudo de la ciudad, donde se retrataron también las escenas consideradas prototípicas que tenían lugar dentro de sus hogares, por más modestos que éstos fueran.

69 Barbosa, El trabajo en las calles, p. 166.

70 Sin autor, Loa dicha por un barillero en honor de María Santísima de los Dolores [Imp. Antonio Vanegas Arroyo], sin fecha. Col. Blaisten. 


\section{LA ECONOMÍA DOMÉSTICA EN DISPUTA}

Los vínculos entre hombres y mujeres fueron un conjunto temático recurrente en la producción impresa de Vanegas Arroyo, sus herederos y sus émulos. En éste, al igual que en los demás ámbitos de su labor, pudieron abrevar de una tradición literaria muy asentada y difundida en el contexto iberoamericano, la cual abarca un rango inmenso entre el amor cortés y la violencia sexual. Algunas hojas volantes del periodo considerado, sin embargo, permiten atisbar ciertas expresiones específicas operadas en las relaciones de género y su representación atingente a los habitantes más pobres de la ciudad de México.

Mientras algunas composiciones retratan diálogos entre unas imaginarias madres y sus hijas recientemente desposadas (oscilando entre el conciliábulo o la instigación contra el yerno y el consejo pacificador), ${ }^{71}$ las más de las veces se escenifican enfrentamientos nada amigables entre suegra y yerno. A la par, abundan los contrapuntos protagonizados por mujer y esposo. Los últimos llevan a formarse una idea de la convivencia conyugal como una instancia ingrata, plena de altercados, de la cual hubiera estado erradicado el transcurso apacible de la vida y, con mayor razón, el amor o el cariño.

"Mi mujer todos los días/ Me atormenta con lo mismo:/ ‘No alcanza lo que me das!’”, se quejó un marido, y, dirigiéndose a su cónyuge: “¡Mujer, por Santo Tobías!/ ¿Tienes

71 Con las suegras poco y bueno, si no tendrán un infierno. Reproducido en López Casillas, Manilla, p. 119. 
aún el cinismo/ De querer que te dé más?". ${ }^{2}$ El tema de los recursos económicos del grupo familiar, su obtención, la manera de distribuirlos y administrarlos, articuló un espectro amplio de significados culturales en torno al género.

Fincaron aquí las obligaciones de los hombres pertenecientes a las clases trabajadoras y las consecuentes expectativas femeninas. ${ }^{73} \mathrm{Su}$ incumplimiento podía llevar, en casos extremos, a la violencia doméstica. De acuerdo con distintos testimonios de la época, entre otros, los propios corridos sobre crímenes acaecidos en el ámbito familiar, tales actos fueron denunciados como ultrajes si no había, como contraparte mínima, la observancia de determinadas obligaciones, comenzando por el sustento material. En una escena dialogada de la Imprenta Guerrero, una mujer recrimina a su consorte: "Ya me rompiste la cara,/ eso sí sabes hacer,/ pero dame de comer;/ eso sí que no te toca;/ me tienes como una loca,/ no me sacas a pasear", fechoría agravada si "te emborrachas a tu gusto;/ para mí no hay un centavo/ pero al fin dices, al cabo,/ yo me la paso sin susto". ${ }^{74}$

Las parejas imaginarias de los impresos en cuestión, contrariando la experiencia común (y aquello demostrado por la historiografía), apelan a un ordenamiento social donde corresponde en exclusiva a los varones adultos obtener y administrar el sustento material de la mujer y los vástagos.

${ }_{72}$ Sin autor, La pobreza reinante, Imp. Antonio Vanegas Arroyo, 1912. BDCV, Corridos Populares, 193.

73 Arrom, Las mujeres, p. 197.

${ }^{74}$ Pérez, Candelario, Discusión entre casados, Imprenta Guerrero, sin fecha. BDCV, Corridos Populares, 100. Desarrollo parecido en Sin autor, Reciente pleito de casados, que si no riñen están enojados, Imp. Antonio Vanegas Arroyo, sin fecha. BDCV, Corridos Populares, 160. 
Ello, a pesar de que en la ciudad de México el aporte económico de las mujeres era considerable, correspondiendo a más de un tercio de la fuerza de trabajo en 1848, según cifras oficiales, proporción que se mantuvo hasta las primeras décadas del siglo xx. ${ }^{75}$ Los mismos corridos, por otra parte, refieren una situación un tanto idealizada, donde hombres y mujeres han formalizado su relación a través de un vínculo legal o socialmente sancionado. Dan a entender que todos los protagonistas integran un matrimonio "bien constituido", imagen contrastante con una realidad mucho más diversa, incluyendo numerosos grupos familiares al margen del lazo conyugal y parejas que cohabitaban de forma temporal o permanente en igual situación, junto con muchas más que incorporaban miembros externos al ideal de la familia nuclear burguesa. ${ }^{76}$

¿Qué permiten conocer las composiciones analizadas sobre cuanto sentían quienes daban forma a los hogares modestos, pese a lo antedicho? De partida, que los papeles de género entraban en tensión en momentos de penuria económica generalizada, incluso años después de finalizada la fase armada de la revolución. Cuando la sensación de pobreza era tanta, que el único en los barrios pobres capaz de mantener algún ingreso era el dueño del molino de maíz, las mujeres parecían dispuestas a retomar la molienda casera con ánimo de ahorrar. Algunas, sin embargo, rehuían tal imposición: "Así dicen que no hay hombres/ ni quien se quiera casar,/ quién ha de querer a flojas/ que no saben ni

\footnotetext{
75 Arrom, Las mujeres, p. 197; Thompson, “The Structures”, p. 407.

76 Thompson, "The Structures", pp. 415-416 y García Peña, "Madres solteras”, pp. 658-661.
} 
tortear". ${ }^{77}$ La gran ciudad podía, ciertamente, implicar una oportunidad para las mujeres pobres, pues tanto ellas como los hombres de su mismo rango social veían trastocados los parámetros habituales de su antigua vida pueblerina en prácticamente todos los ámbitos. ${ }^{78}$

En el nuevo escenario citadino, por lo mismo, los deberes de hombres y mujeres dentro del lazo conyugal debían ser refrendados de continuo. Según una composición satírica firmada por José Guerrero hacia 1915, una pareja joven establecía los límites de la relación en los siguientes términos. Ella esgrimía que "ya hasta enseñas lo de atrás,/ no te compras ni calzones,/ comes porque te mantengo,/ agradece a mis pulmones/ pues tú y toda tu familia/ son atajo de bribones". Luego de un intercambio de argumentos muy áspero, el inexperto marido decía hastiado: "al fin que tengo dinero/ de todo lo que he ganado,/ hoy me voy con las muchachas/ de esas de puro melado", aserto tenido como confesión por su esposa, con graves consecuencias: “Con eso quieres decir/ que te encuentras bien armado/ y ahora que tienes dinero/ la obligación te ha pesado,/ sinvergüenza descarado,/ no me tienes compasión,/ yo ya no tengo camisa,/ ando enseñando el pulmón,/ ahora que tienes dinero/ cómprame mi camisón”.

Guerrero, Eduardo, Crisis monetaria, Imprenta Guerrero, sin fecha. BDCV, Corridos Populares, 94. Durante los años de la Revolución, aquello podía afectar también a las mujeres de otros estratos sociales: "Las catrinas pretenciosas/van al molino de prisa,/ todas se ponen formadas,/ tiesas como longaniza". Sin autor, Nuevas coplas de la cucaracha, Imprenta Guerrero, sin fecha. BDCV, Corridos Populares, 269.

${ }^{78}$ Véase, entre otros, Huerta, Pedro, Nueva bola de hombres y mujeres, sin imprenta, sin fecha. BDCV, Corridos Populares, 123. 
Momentáneamente, al menos, los imperativos maritales parecían verificarse. Desde el punto de vista del esposo, el razonamiento era simple ante tal exigencia: "No más porque eres mi vieja/ y me guisas los frijoles/vámonos al Baratillo,/ pues allí hay de los mejores [camisones]”, y esa respuesta positiva contaba con buena aceptación de parte de ella: "Ah! qué lindo eres, chinito/ del cabello encarrujado,/ eres un amante fiel/ y el hombre más educado,/ lo que hagas es de mi agrado,/ yo nunca te contradigo/ porque sé que como esposo/ eres mi mejor amigo" ${ }^{79}$

En cuanto a los varones en particular, los años de "la bola" fueron sentidos como un periodo arduo, durante el cual, sin embargo, cabía la posibilidad de escapar de la miseria y recorrer el país teniendo aventuras en compañía de otros varones. Para expresar este sentir, Felipe Flores arregló unas cuartetas diciendo: "Cuando andaba de pelón/ Y vivía de la juaneada,/ Nunca me faltó un tostón,/ Para mi chínguere o baba”. Luego de seguir a Madero, Zapata y Villa, y ya acabado el periodo de lucha armada, "Me vine decepcionado/ Al Distrito Federal,/Y con fuero, un diputado/ Un día me iba á asesinar”, asunto de peor pronóstico por la crisis laboral en la ciudad: "Seguí buscando trabajo/ En donde hubiera vacantes/ Y en lugar de hallar tasajo/ Encontré puros cesantes!" ${ }^{80}$ Pasados esos años, la actividad

79 Guerrero, José, El pleito de casados, sin imprenta, sin fecha. BDCV, Corridos Populares, 99. Nótese que la reconciliación es aparente y momentánea. Los últimos versos cuentan que el hombre golpeó ferozmente a su esposa, después de lo cual "al verla ya tan humilde/ se le ablandó el corazón/ y la llevó al Baratillo/ a comprarle el camisón”.

${ }^{80}$ Flores, Felipe, ¿Qué haremos con la brujez? [Imprenta Guerrero], sin fecha. BDCV, Corridos Populares, 13. En otro texto, una mujer dice a su 
económica en declive significaba una odisea tremenda para quienes buscaban empleo y un eventual menoscabo para un ángulo preciso de la masculinidad popular. Según dijo una esposa encarando a su marido: "Todos encuentran trabajo/ Sólo tú eres desgraciado;/ Pero es que eres un flojo/ Que quieres estar sentado,/ Yo por ti estoy padeciendo,/ Porque si solita fuera/ Me fuera de planchadora/ O me metiera a estanquera", y la amenaza consiguiente: "Si desde hoy no traes el diario/ No me vuelvas aquí a entrar,/ Yo b[usc]caré por ahí otro/ Que no me haga trabajar”. ${ }^{81}$

Una gran disparidad entre cuanto dictaban las normas sociales y legales, y aquello realmente sucedido respecto de las imposiciones patriarcales, ha sido asentado vastamente por la historiografía. Misma cosa puede afirmarse sobre las distancias entre el discurso literario y las pautas de conducta observadas por hombres y mujeres que poblaron la ciudad de México. ${ }^{82}$ Tratándose de una literatura marginal o "marginada", ${ }^{83}$ con todo, sorprende la capacidad de sus cultores para mostrar a su auditorio inmediato cuánto y cómo podía cambiar en la capital un agregado de normas y expectativas tan reacias a modificarse, como aquellas relativas a lo masculino y lo femenino. El tópico de los recursos económicos familiares dio pie, en los corridos impresos de

marido: "métete de Villista/ y me traerás doce reales". Sin autor, Diálogo divertido entre mujer y marido, Imp. Antonio Vanegas Arroyo, sin fecha. BDCV, Corridos Populares, 250.

${ }^{81}$ Sin autor, La Arranquera, Imp. Testamentaría de A. Vanegas Arroyo, sin fecha. BDCV, Corridos Populares, 139. También Pérez, Juan, Quemazón $3^{a}$ parte. Pleito de suegras y yernos, sin imprenta, sin fecha. BDCV, Corridos Populares, 146.

${ }^{82}$ Arrom, Las mujeres, pp. 24-27.

${ }^{83}$ García de EnTERría, Literaturas marginadas, p. 23. 
principios del siglo $\mathrm{xx}$, a la irrupción definitiva de un tipo social más tarde modelado por los medios y la cultura popular de masas con singular inquina: la suegra.

Conocida es la influencia casi incontrarrestable de las generaciones mayores en el sistema de relaciones de género vigente en México hasta las primeras décadas del siglo XIX. En ámbitos rurales, mujeres y varones jóvenes de los sectores subordinados debían enfrentar el control parental, incluso si ya habían formalizado su vínculo afectivo y aspiraban a formar una nueva familia. ${ }^{84}$ La figura que epitomizaba tal control y se alzaba como autoridad familiar e interlocutor frente a la comunidad era masculina: el abuelo -si aún era productivo económicamente- o el padre -en plenas funciones-. En las manifestaciones culturales que recrean la cotidianeidad urbana de los mexicanos pobres finalizando la misma centuria, esa figura está ausente. ${ }^{85} \mathrm{En}$ su reemplazo, tal vez como evidencia de un reordenamiento mayor, asoma su contraparte femenina, encarnada por la madre o la suegra. Es, en todo caso, sólo un remedo de autoridad. El suyo es un estatuto algo ambiguo, próximo a la picaresca y revestido de cierta bajeza moral. Pareciera, en primera instancia, intentar algún control sobre el patrimonio de las

${ }^{84}$ No es mi intención discutir un panorama social tremendamente complejo. Para ello véase, entre otros, STERn, La historia secreta y García PEÑA, "Madres solteras". La cuestión normativa para el periodo analizado fue estudiada por Ramos Escandón, "Mujeres positivas".

85 En cambio, sí aparece en corridos escenificados en el espacio rural, donde era más plausible. Por ejemplo, una disputa intergeneracional entre hombres por el control sexual de las mujeres jóvenes, en Sin autor, El ranchero y el gavilán, Imp. Antonio Vanegas Arroyo, 1913. BDCV, Corridos Populares, 238. 
parejas jóvenes y supervisar las imposiciones genéricas que le caben a su hijo político:

-Oyeme, yerno maldito,
Tú pareces un muchacho,
No sabes de obligaciones
Pero así andas de borracho,
Ya de mi hija no haces caso,
Hay [sic] la tienes encuerada,
Mal comida y bien golpeada.
-Ya a su hija no la quiero;
Ya tengo otra más mejor,
Parece estrella del cielo
Como la luna y el sol.
La traigo muy bien vestida
Y ella se llama Leonor,
Trae sus botas amarillas
Y un rebozo tornasol. ${ }^{86}$

Si de razones se trata, aquellas espetadas por el varón interpelado resultan bastante claras en medio de sus palabras malsonantes: “Cállese, vieja choriza,/ ¿Por qué me está regañando?/ Si su hija es muy berijona,/ No me hace ni una camisa,/ Ni remienda sus enaguas,/ ¡Demonio de cacariza!/ Y así quiere que le quiera”. ${ }^{87}$ Desde el punto de vista masculino, cabía entre las expectativas de la convivencia matrimonial que las mujeres fueran diligentes y se ocuparan cuando

86 Pérez, Juan [¿seud.?], Quemazón $1^{a}$ parte. Pleito de suegras y yernos, sin imprenta, sin fecha. BDCV, Corridos Populares, 47.

87 Pérez, Juan [¿̇seud.?], Quemazón $1^{a}$ parte. Pleito de suegras y yernos, sin imprenta, sin fecha. BDCV, Corridos Populares, 47. 
menos de su presentación personal, junto con la de todo el grupo familiar.

Aquello era fundamental para una actividad social acorde con el ritmo impuesto por la vida en la ciudad y la propia urbanidad exigida a sus residentes nuevos o antiguos. ${ }^{88}$ Sintomática resulta, de todas formas, la expresión de un imperativo de género relativo a las mujeres pobres, en términos relacionados con la confección o el remiendo de las ropas. Ello trasluce una privación material, en una sociedad donde la vestimenta podía ser un gasto oneroso, casi una inversión (muy alejado de nuestros patrones de consumo actuales), demandante en consecuencia de varias precauciones para mantenerla, pero es también un eco cultural de tradición muy antigua acerca de las labores domésticas de las mujeres.

La contendora de la citada hoja, desde su trinchera, aduce otros argumentos. Ya que su yerno la envía “ ¡a jugar con sus muñecas,/ No con un hombre cabal!”, la suegra contesta despectivamente: "Juego con otros mejores,/ cuanto más con este mono/ de barro de Tonalá,/ cara de zapote prieto,/ retrato de Satanás,/ manco, chueco y además/ tuerto, borracho y greñudo/ cara de pambazo crudo". ${ }^{89}$ El habla denigratoria de la suegra termina volviéndose en su contra y de forma unánime es condenada en todas las composiciones estudiadas. Su mera presencia, en definitiva, se revela un total incordio para el desenvolvimiento de las familias jóvenes.

88 De Simone, "La moda".

${ }^{89}$ Pérez, Juan [¿seud.?], Quemazón $1^{a}$ parte. Pleito de suegras y yernos, sin imprenta, sin fecha. BDCV, Corridos Populares, 47. Improperios de igual calibre en Ya la vieja de mi suegra no más quiere regañar. De a tiro la corta verde, no la deja madurar, reproducido en López CASILLAS, Manilla, p. 120. 
Las suegras parecen tener una animadversión visceral contra los yernos y cargar las tintas sobre cuanto de ellos se esperaba en términos de su posición social. ${ }^{90} \mathrm{Si}$ bien el estipendio económico podía considerarse un deber masculino desde el mismo cortejo, ${ }^{91}$ quienes formaban los hogares de las colonias populares contaban con las herramientas para debatir sus problemas por sí mismos y solucionarlos sin la injerencia de los mayores. La renegociación de los términos de la cotidianeidad conyugal, como se ha visto, era habitual y una mujer no precisaba de interlocutores para espetar directamente a su esposo: "no quieres más que vivir/ en la sola pulquería,/ allí estás de noche y día/ y dejas sola tu casa,/ ya no tengo para masa/ ni para comprar jabón,/ y el día treinta hay que pagar/ los cinco pesos de casa". ${ }^{92}$ Creyendo haber cumplido, por su parte, el marido asimismo exigía retribución: "Por eso [,] vez que trabajo/ y que me suda la frente,/ pues ahora debo comer/ como la gente decente:/ me has de dar agua caliente/ y café embotellado,/ un pollito bien asado,/ la salsa y el vinagrito,/ el pan que esté bien tostado/ y que no falte el pulquito". ${ }^{93}$

Los corridos citados no tienen una intención realista, cuanto de mordaz crítica social. Describen, sí, un estado de

90 "Porque no le quiero á su hija,/ Ni la quiero mantener,/ Esa dientes de clavija/ Nunca me ha podido ver.” Pérez, Juan [¿̇seud.?], Quemazón $2^{a}$ parte. Pleito de suegras y yernos [Imprenta Guerrero], sin fecha. BDCV, Corridos Populares, 68.

91 Juan [sic], El enamorado arrepentido, Imprenta Guerrero, sin fecha. BDCV, Corridos Populares, 122.

92 Sin autor, Diálogo divertido entre mujer y marido, Imp. Antonio Vanegas Arroyo, sin fecha. BDCV, Corridos Populares, 250.

93 Sin autor, Diálogo divertido entre mujer y marido, Imp. Antonio Vanegas Arroyo, sin fecha. BDCV, Corridos Populares, 250. 
cosas respecto a las relaciones de género de las clases trabajadoras urbanas. Aflora en diálogos y escenas una ansiedad creciente sobre un conjunto de normas y expectativas trastocado por los procesos de modernización social vividos en la ciudad de México, agravados por un ciclo económico crítico. Las composiciones en cuestión traslucen, a su vez, una serie de anhelos sobre la vida familiar, la mayoría de los cuales los hogares más modestos estaban lejos de satisfacer y que derivaban de una lectura "desde abajo" de la respetabilidad pequeñoburguesa, así como de una sociabilidad más intensa, aparejada con nuevas pautas de consumo. ${ }^{94}$

\section{LA CIUDAD A RAS DE CALLE}

Cabe agregar un par de palabras para finalizar, confiando en que habrá quedado a la vista el potencial de los corridos para aprehender la ciudad de México desde otra perspectiva. Es innegable que éstos amplían nuestro conocimiento del devenir de la urbe, si bien imponen una serie de desafíos para el análisis histórico. Se debe considerar, de parti$\mathrm{da}$, el factor del soporte impreso. Eso nos recuerda que los versos de las hojas volantes pueden tratar contenidos vernáculos, inmemoriales casi, y registrar temas tradicionales, pero actualizados y en pleno contacto con el presente de su puesta en circulación. Desde un punto de vista metodológico, en consecuencia, texto poético, formato impreso y soporte material son inseparables. Estas tres dimensiones

${ }_{94}$ Por ejemplo, el cine como espectáculo habitual. Sin autor, La pobreza reinante, Imp. de Antonio Vanegas Arroyo, 1912. BDCV, Corridos Populares, 193. 
interrelacionadas de la práctica cultural en cuestión fueron las que articularon un discurso distintivo, capaz, sin embargo, de dialogar abiertamente con los patrones culturales más dinámicos -en camino de convertirse en hegemónicos- emanados desde posiciones enunciativas socialmente distintas.

Para algunos letrados de la época, era ése el motivo por el cual la poesía y el pueblo mismo ya no eran "genuinamente populares"-léase campesinos-, sino "vulgares", en tanto se habían "contaminado" con las formas culturales urbanas y foráneas, en particular en virtud de la prensa, la cual por medio del cable relataba sucesos de tierras remotas en tiempos cada vez más inmediatos. ${ }^{95}$ El discurso de la lírica popular, en efecto, sólo podría haberse desarrollado en un escenario urbano, donde poetas, impresores y vendedores de corridos fueron mediadores entre la producción cultural impresa y quienes no poseían competencias lectoras acabadas. ${ }^{96}$ Tendieron así puentes entre aquello considerado cultura legítima por las clases dominantes y las proteicas manifestaciones culturales de los nuevos ocupantes de la capital.

Ahí radica buena parte de la riqueza de los corridos para volver a interrogar el pasado, aunque los canónicos “¿qué sucedió?” o “¿por qué sucedió?”, del arsenal historiográfico, ceden paso a una búsqueda del sentido atribuido a las representaciones construidas con un habla poética particular. En efecto, no resulta tan imprescindible estudiar ésta para rastrear información factual (eventualmente

${ }_{95}$ Illades, "Pueblo y plebe", p. 371; Mendoza, El romance español, pp. 125 y 131.

${ }^{96}$ Martín-Barbero, De los medios, pp. 133-134; Botrel, Libros, p. 132. 
complementaria o cuestionadora de otros documentos de naturaleza diferente), ni dar relieve a una práctica cultural de sobra conocida, si bien no explorada por los historiadores. Como otras manifestaciones del campo cultural, la lírica popular del México de entre siglos evidencia cómo un sector de la población recibió de manera favorable, o bien se opuso, a los dictados de los grupos dominantes. En este caso particular, de modo bastante paradójico, puesto que echó mano de una forma literaria en apariencia arcaizante, adaptada en un soporte moderno, habilitado para interpelar las corrientes más avasalladoras de un mercado de bienes impresos cada vez más complejo.

Respecto al tema que nos convoca, las hojas volantes salidas mayoritariamente de las prensas de Antonio Vanegas Arroyo y Eduardo Guerrero, en tanto registro histórico permiten acceder al modo en que los protagonistas menos afortunados de la modernización de la ciudad de México vislumbraron dicho proceso. Es una mirada crítica, sin dudas, a contrapelo del relato institucional -lineal y progresista, interrumpido sólo a medias por la revolución-, pero también divergente de la crítica letrada, sea ésta gremial (arquitectos, urbanistas, ingenieros) o literaria. Porque, sin olvidar a Ángel Rama, vates, cantores y público preferente de los corridos no tenían las llaves de la "ciudad letrada", sino que habitaban en sus extramuros, territorio de la "ciudad real". El suyo fue, en consecuencia, un urbanismo poético y popular, contrario a componer sinfonías laudatorias o estampas inquietantes de flâneur modernista y bohemio.

Fue, además, un urbanismo irreductible a la condición de discurso unitario. Los copleros anónimos, los que firmaron, Vanegas y Guerrero, reflexionaron en innumerables 
oportunidades sobre la ciudad, aunque con una intención muy otra a trazarla en caracteres definitivos. Antes bien, con versos chispeantes y diálogos certeros, diseñaron una cartografía imprecisa tal vez para nosotros, pero plena de significado para hombres y mujeres que se aventuraron a vivir la ciudad del cambio de siglo. Lejos de menoscabar la virtud del material analizado como documento histórico, esta cualidad discursiva conduce a una comprensión más compleja del fenómeno urbano. La posibilidad cierta de examinar otras colecciones de similar tenor, de igual forma, es una invitación a interrogar a la ciudad con más voces.

\section{SIGLAS Y REFERENCIAS}

BDCV Biblioteca Daniel Cosío Villegas, El Colegio de México, ciudad de México.

Col. Blaisten Colección Andrés Blaisten, fondo Díaz de León, ciudad de México.

Abreu, Márcia

Histórias de cordéis e folhetos, Campinas, Mercado de Letras, Associação de Leitura do Brasil, 1999.

Almandoz, Arturo

Entre libros de historia urbana. Para una historiografía de la cindad y el urbanismo en América Latina, Caracas, Equinoccio, Universidad Simón Bolívar, 2008.

Aréchiga, Ernesto

"Lucha de clases en la ciudad. La disputa por el espacio urbano, ca. 1890-1930”, en Illades y Barbosa (coords.), 2013, pp. 19-50. 
Arrom, Silvia Marina

Las mujeres de la ciudad de México, México, Siglo Veintiuno Editores, 1988.

Avitia, Antonio

Corridos de la capital, México, Dirección General de Culturas Populares, Conaculta, 2000.

Bajtin, Mijail

La cultura popular en la Edad Media y en el Renacimiento. El contexto de François Rabelais, Madrid, Alianza Editorial, 1998.

Barbosa, Mario

El trabajo en las calles. Subsistencia y negociación politica en la ciudad de México a comienzos del siglo xx, México, El Colegio de México, Universidad Autónoma Metropolitana-Cuajimalpa, 2008.

Bollème, Geneviève

La Bibliothèque Bleue. La littérature populaire en France du $X V I I^{e}$ au XIX ${ }^{e}$ siècle, París, Gallimard-Julliard, 1971.

Bonilla, Helia Emma

"Imágenes de Posada en los impresos de Vanegas Arroyo", en Clark de Lara y Speckman (eds.), 2005, pp. 415-436.

Botrel, Jean François

Libros, prensa y lectura en la España del siglo XIX, Madrid, Fundación Germán Sánchez Ruipérez, 1993.

Campo, Ángel de

La Semana Alegre. Tick-Tack, Miguel Ángel Castro (comp.), México, Universidad Nacional Autónoma de México, 1991.

Campos, Rubén M.

El folklore literario de México. Investigación acerca de la producción literaria popular (1525-1925), México, Publicaciones de la Secretaría de Educación Pública, 1929. 
Clark de Lara, Belem y Elisa Speckman (eds.)

La República de las letras. Asomos a la cultura escrita del México decimonónico, México, Universidad Nacional Autónoma de México, 2005, t. II.

Chartier, Roger

"Lecturas populares. La Bibliothèque Bleu", en Elpresente del pasado: escritura de la historia, historia de lo escrito, México, Universidad Iberoamericana, 2005, pp. 167-192.

Castillo, Alberto del

"El surgimiento de la prensa moderna en México", en CLARK de Lara y Speckman (eds.), 2005, t. II, pp. 105-118.

Castro, Miguel Ángel (ed.)

Pueblo y canto. La ciudad de Ángel de Campo, 'Micrós'y TickTack. Homenaje en el centenario de su muerte, México, Universidad Nacional Autónoma de México, 2011.

De Certeau, Michel

La invención de lo cotidiano, México, Universidad Iberoamericana, 2000.

De Simone, Liliana

"La moda: hacia una comprensión de la sociedad de consumo en la ciudad moderna”, en Márquez (ed.), 2012, pp. 97-113.

ELKins, Charles

"The Voice of the Poor: The Broadside as a Medium of Popular Culture and Dissent in Victorian England", en Journal of Popular Culture, 14:2 (1990), pp. 262-274.

Freeman, Rachel

"The making of the Mexican broadside print: technical note", en Miliotes, 2006, pp. 37-40.

Fritzche, Peter

Berlin 1900: prensa, lectores y vida moderna, Buenos Aires, Siglo Veintiuno editores, 2008. 
García Cubas, Antonio

El libro de mis recuerdos. Narraciones históricas, anecdóticas y de costumbres mexicanas anteriores al actual orden social, ilustradas con quinientos grabados [1905], México, Porrúa, 1986.

García de Enterría, María Cruz

Literaturas marginadas, Madrid, Playor, 1983.

García Peña, Ana Lidia

"Madres solteras, pobres y abandonadas: ciudad de México, siglo XIX”, en Historia Mexicana, LIII:3 (211) (ene.-mar. 2004), pp. 647-692.

Giménez, Catalina H. de

Asícantaban la revolución, México, Grijalbo, Consejo Nacional para la Cultura y las Artes, 1990.

Girón, Nicole

"La folletería durante el siglo xix", en Clark de LARA y SPECKMAN (eds.), 2005, pp. 375-390.

González, Aurelio

"El corrido: expresión popular y tradicional de la balada hispánica”, en Olivar, 15 (2011), pp. 11-36.

Gorelik, Adrián

La grilla y el parque. Espacio público y cultura urbana en Buenos Aires, 1887-1936, Buenos Aires, Universidad Nacional de Quilmes, 1998.

Gretton, Thomas

"De cómo fueron hechos los grabados de Posada", V.V.A.A., Posada y la prensa ilustrada: signos de modernización y resistencias, México, Instituto Nacional de Bellas Artes, 1996, pp. 121-149. 
Harvey, David

París, capital de la modernidad, Madrid, Akal, 2008.

Herrera, Celestino (comp.)

Corridos de la revolución, Pachuca, Ediciones del Instituto Científico y Literario, 1934.

Illades, Carlos

"Pueblo y plebe en la literatura mexicana de la segunda mitad del siglo XIX”, en Castro (ed.), 2011, pp. 371-377.

Illades, Carlos y Mario BARbosa (coords.)

Los trabajadores de la cindad de México, 1860-1950. Textos en homenaje a Clara E. Lida, México, El Colegio de México, 2013.

Joyce, Patrick

Visions of the People. Industrial England and the Question of Class, 1848-1914, Cambridge, Cambridge University Press, 1991.

López Casillas, Mercurio

José Guadalupe Posada, ilustrador de cuadernos populares, México, R.M. (Biblioteca de Ilustradores Mexicanos), 2003.

Manilla. Monografía de 598 estampas de Manuel Manilla, grabador mexicano, México, R.M., 2005.

Marco, Joaquín

Literatura popular en España en los siglos XVIII y XIX, Madrid, Taurus, 1977.

Marcus, Sharon

Apartment Stories. City and Home in Nineteenth-Century Paris and London, Berkeley, University of California Press, 1999. 
MÁrquez, Francisca (ed.)

Ciudades de Georg Simmel. Lecturas contemporáneas, Santiago, Ediciones Universidad Alberto Hurtado, 2012.

Martín-Barbero, Jesús

De los medios a las mediaciones. Comunicación, cultura y hegemonía, Bogotá, Convenio Andrés Bello, 2003.

Mendoza, Vicente T.

El romance español y el corrido mexicano. Estudio comparativo, México, Ediciones de la Universidad Nacional, 1939.

Miliotes, Diane

José Guadalupe Posada and the Mexican Broadside, New Heaven y Londres, The Art Institute of Chicago, Yale University Press, 2006.

Monnet, Jerôme

“PPoesía o urbanismo? Utopías urbanas y crónicas de la ciudad de México (siglos xvi a xx)", en Historia Mexicana, xxxix:3 (155) (ene.-mar. 1990), pp. 727-766.

Outtes, Joel e Irene Kazumi Miura

"Disciplinar a la sociedad por medio de la ciudad: la génesis del urbanismo en Brasil y Argentina (1894-1945)”, en Secuencia, 57 (2003), pp. 124-156.

Pérez Montfort, Ricardo

"La fiesta y los bajos fondos. Aproximaciones literarias a la transformación de la sociedad urbana en el México del siglo xx", en Estampas de nacionalismo popular mexicano. Diez ensayos sobre cultura popular y nacionalismo, México, Centro de Investigaciones y Estudios Superiores en Antropología Social, 2003, pp. 47-78.

Pineo, Ronn y James A. Baer

“Urbanization, the Working Class, and Reform”, en Pineo y BAER (eds.), 1998, pp. 258-271. 
Pineo, Ronn y James A. Baer (eds.)

Cities of Hope. People, Protests, and Progress in Urbanizing Latin America, 1870-1930, Boulder y Oxford, Westview Press, 1998.

POSADA

José Guadalupe Posada, ilustrador de la vida mexicana, México, Consejo Nacional para la Cultura y las Artes, 1992.

Quirarte, Vicente

Elogio de la calle. Biografía literaria de la Ciudad de México, 1850-1992, México, Cal y Arena, 2001.

Ramos, Julio

Desencuentros de la modernidad en América Latina. Literatura y política en el siglo XIX, México, Fondo de Cultura Económica, 1989.

Ramos Escandón, Carmen

"Mujeres positivas: los retos de la modernidad en las relaciones de género y la construcción del parámetro femenino en el fin de siglo mexicano, 1880-1910", en SPeckman y AgostoNI (comps.), 2001, pp. 291-317.

Rodríguez Kuri, Ariel

Historia del desasosiego. La revolución en la ciudad de México, 1911-1922, México, El Colegio de México, 2010.

La experiencia olvidada. El Ayuntamiento de México: politica y gobierno, 1876-1912, México, El Colegio de México, Universidad Autónoma Metropolitana-Azcapotzalco, 2011.

Romero, José Luis

Latinoamérica: las cindades y las ideas, México, Siglo Veintiuno editores, 1984.

Rotker, Susana

La invención de la crónica, México, Fondo de Cultura Económica, Fundación para un Nuevo Periodismo Iberoamericano, 2005. 
Simmons, Merle E.

The Mexican Corrido as a Source for Interpretive Study of Modern Mexico (1870-1950), Nueva York, Kraus Reprint Co., 1969.

Speckman, Elisa

"Cuadernillos, pliegos y hojas sueltas en la imprenta de Antonio Vanegas Arroyo", en Clark de Lara y Speckman (eds.), 2005, pp. 391-413.

Speckman, Elisa y Claudia Agostoni (comps.)

Modernidad, tradición y alteridad. La ciudad de México en el cambio de siglo $(X I X-X X)$, México, Universidad Nacional Autónoma de México, 2001.

STERn, Steve

La historia secreta del género. Mujeres, hombres y poder en México en las postrimerías del periodo colonial, México, Fondo de Cultura Económica, 1999.

Thompson, Lanny

"The Structures and Vicissitudes of Reproduction: Households in Mexico, 1876-1970", en Review (Fernand Braudel Center), 14:3(1991), pp. 403-436.

Valenzuela, Alfonso

"Racionalidad y poder. Las elites en la Ciudad de México, 1876-1940”, en Iberoamericana, XII: 47(2012), pp. 9-27.

Viveros, Luz América

"De puertas adentro: interiores y umbrales urbanos finiseculares", en Castro (ed.), 2011, pp. 119-126. 
